GHOST OF $0.7 \%$ :

ORIGINS AND RELEVANCE OF THE

INTERNATIONAL AID TARGET

By Michael A. Clemens and Todd J. Moss

Abstract
The international goal for rich countries to devote $0.7 \%$ of their national income to
development assistance has become a cause célèbre for aid activists and has been
accepted in many official quarters as the legitimate target for aid budgets. The origins of
the target, however, raise serious questions about its relevance. First, the $0.7 \%$ target was
calculated using a series of assumptions that are no longer true, and justified by a model
that is no longer considered credible. When we use essentially the same method used to
arrive at $0.7 \%$ in the early 1960 s and apply today's conditions, it yields an aid goal of just
$0.01 \%$ of rich-country GDP for the poorest countries and negative aid flows to the
developing world as a whole. We do not claim in any way that this is the 'right' amount
of aid, but only that this exercise lays bare the folly of the initial method and the
subsequent unreflective commitment to the $0.7 \%$ aid goal. Second, we document the fact
that, despite frequent misinterpretation of UN documents, no government ever agreed in a
UN forum to actually reach 0.7\%- though many pledged to move toward it. Third, we
argue that aid as a fraction of rich country income does not constitute a meaningful
metric for the adequacy of aid flows. It would be far better to estimate aid needs by
starting on the recipient side with a meaningful model of how aid affects development.
Although aid certainly has positive impacts in many circumstances, our quantitative
understanding of this relationship is too poor to accurately conduct such a tally. The $0.7 \%$
target began life as a lobbying tool, and stretching it to become a functional target for real
aid budgets across all donors is to exalt it beyond reason. That no longer makes any
sense, if it ever did.




\title{
GHOST OF 0.7\%: \\ ORIGINS AND RELEVANCE OF THE INTERNATIONAL AID TARGET
}

\author{
Michael A. Clemens and Todd J. Moss ${ }^{1}$
}

September 6, 2005

\begin{abstract}
The international goal for rich countries to devote $0.7 \%$ of their national income to development assistance has become a cause célèbre for aid activists and has been accepted in many official quarters as the legitimate target for aid budgets. The origins of the target, however, raise serious questions about its relevance. First, the $0.7 \%$ target was calculated using a series of assumptions that are no longer true, and justified by a model that is no longer considered credible. When we use essentially the same method used to arrive at $0.7 \%$ in the early 1960 s and apply today's conditions, it yields an aid goal of just $0.01 \%$ of rich-country GDP for the poorest countries and negative aid flows to the developing world as a whole. We do not claim in any way that this is the 'right' amount of aid, but only that this exercise lays bare the folly of the initial method and the subsequent unreflective commitment to the $0.7 \%$ aid goal. Second, we document the fact that, despite frequent misinterpretation of UN documents, no government ever agreed in a UN forum to actually reach $0.7 \%$ - though many pledged to move toward it. Third, we argue that aid as a fraction of rich country income does not constitute a meaningful metric for the adequacy of aid flows. It would be far better to estimate aid needs by starting on the recipient side with a meaningful model of how aid affects development. Although aid certainly has positive impacts in many circumstances, our quantitative understanding of this relationship is too poor to accurately conduct such a tally. The $0.7 \%$ target began life as a lobbying tool, and stretching it to become a functional target for real aid budgets across all donors is to exalt it beyond reason. That no longer makes any sense, if it ever did.
\end{abstract}

\footnotetext{
${ }^{1}$ Michael Clemens (mclemens@cgdev.org) and Todd Moss (tmoss@cgdev.org) are Research Fellows at the Center for Global Development. We thank Sartaj Aziz, Ernest Stern, and C. Fred Bergsten for their insights on the Pearson Commission, Scott Standley for research assistance, and Nancy Birdsall, Charles Kenny, Carol Lancaster, and David Roodman for comments on an earlier draft. All judgments, opinions, and errors are those of the authors alone.
} 


\section{Introduction}

The international goal for rich countries to devote $0.7 \%$ of their national income to development assistance has become a cause célèbre for aid activists and, lately, politicians. However ubiquitous and durable, the target of $0.7 \%$ was never meant to represent the 'right' level of aid needed by poor countries. A look at its history shows that it was calculated using methods with little relevance to today's understanding of the development process, and actually reaching $0.7 \%$ of income in aid was never agreed to by any government or international body prior to 2005. Originally intended as a political tool to goad rich countries to modestly increase their aid budgets, the specific figure of $0.7 \%$ was a compromise between educated guesses based on economic conditions in the early 1960s and on a crude and deeply flawed model of growth. Despite these origins, " $0.7 \%$ " has taken on a life of its own and become a powerful rallying cry for aid proponents. Indeed, in 2005, advocates are demanding that rich countries reach this specific target (and with some success). But there has been little reflection on whether $0.7 \%$ is the right figure, where it comes from, and exactly what the international agreements pertaining to the goal say and do not say.

Here we find that over time $0.7 \%$ has gained prominence well beyond its initial intention and gained credibility as the correct aid goal that it does not deserve. The next section outlines its origins, showing how the target emerged from a confluence of political and academic trends, and then eventually evolved into a political standard. In the third section we ask whether it is still applicable and raise three questions about its continued relevance. We find that if we apply the same assumptions that went into the original formulation to conditions present today, that the updated target would be $0.01 \%$ of rich country income-well below current aid levels for all major donors. Next, we raise questions about the 'financing gap' model used to determine aid targets, showing that it has no theoretical or empirical basis. Finally, we argue that it is backwards to gauge aid levels based on the size of donors instead of the conditions in recipient economies. We do not argue that aid should in fact be greater or lesser, but rather seek to expose the shaky foundations of the $0.7 \%$ target and to question whether this is the right standard by which to judge donors today.

\section{Origins}

The $0.7 \%$ of gross national income (GNI) target has a long history that dates back more than half a century. ${ }^{2}$ As explained below, the eventual target was mostly arbitrary, based on a series of assumptions that no longer are true, and justified by a model that is no longer considered credible. Despite its origins, acceptance of the $0.7 \%$ target increased and the figure has become a political mantra. As global economic conditions changed radically over the second half of the $20^{\text {th }}$ Century, the goal nevertheless remained static.

\section{Political basis}

The World Council of Churches is a Geneva-based organization that has promoted cooperation between different Christian sects since 1948, and claims to represent 400 million people in 100 countries. From its inception the Council was a conduit for cash

\footnotetext{
${ }^{2}$ Many of the early ratios use GNP (equivalent to GNI) as the denominator, giving way to GDP in later years. We use them interchangeably. In 2003, GNI and GDP in the high-income OECD differed by $0.2 \%$.
} 
donations from parishes in rich countries to those in poor countries. At its 1955 Central Committee meeting in Davos, the Council asked Dutch agricultural economist Egbert de Vries, a senior World Bank official and devout Christian, to advise it on its aid efforts. De Vries made the case that no amount of church donations could reasonably do the job and that "a great amount of capital would be needed from the rich nations in order to achieve only a modest increase in the standard of living of the poorer."3

In 1955, total public and private capital flows to poor countries were about 0.5 percent of rich countries' GNI. ${ }^{4}$ The Council's Central Committee, meeting in Denmark in 1958, adopted a statement that "[o]nly with substantial outside aid from the economically more developed countries ... can countries with soundly based development plans hope to carry them through and avert the human disasters that follow from their failure. ... Far more grants and generous loans are essential. ... If at least one per cent of the national income of countries were devoted to these purposes, the picture would become much more hopeful." 5 Though the Council provided no record of how it arrived at the one percent figure, it is unlikely that it was settled on for any other reason than that it was a round number representing roughly a doubling of capital flows from the levels of the mid-1950s. The Council's request was transmitted to several developed countries' missions to the United Nations.

Throughout the late 1950s public and private capital flows all developing countries increased, and by 1960 had reached $0.83 \%$ of rich countries' GNI. ${ }^{6}$ In that year, the United Nations General Assembly called that level "inadequate" and adopted without vote the resolution that it "[e]xpresses the hope that the flow of international assistance and capital should be increased substantially so as to reach as soon as possible approximately 1 per cent of the combined national incomes of the economically advanced countries."7

The 1\% figure got more than just this hopeful nod from the UN. It was supported directly and explicitly - though not publicly_-by rich-country governments. US State Department internal memos from early 1961 reveal that the Undersecretary of State for Economic and Agricultural Affairs “thought the Germans might agree to one per cent of gross national

\footnotetext{
${ }^{3}$ Darrill Hudson (1977), The World Council of Churches in International Affairs (Leighton Buzzard, UK: Faith Press for the Royal Institute of International Affairs), p. 172.

${ }^{4}$ The UN reported that total private and public capital flows from developed countries to developing countries averaged 2.6 billion per year 1951-1955, and 4.7 billion per year 1956-1959 (Proceedings of the United Nations Conference on Trade and Development, Geneva, 23 March-16 June 1964, Volume V, Financing and Invisibles: Institutional Arrangements, Table 1-1, p. 6). We thus assume that the total was around 3.5 billion in 1955. Real GDP growth in the high-income OECD countries averaged $4.5 \%$ between 1955 and 1959 (Angus Maddison [2003], International Historical Statistics [Paris: OECD]), and inflation was roughly $2 \%$ per year (US Bureau of Labor Statistics, ftp://ftp.bls.gov/pub/special.requests/cpi/cpiai.txt). The World Bank's World Development Indicators 2005 CD-ROM says that GNI of the high-income OECD in 1960 was $\$ 972$ billion in current nominal dollars. Allowing for 4.5\% real growth per year and 2\% inflation, this means that high-income OECD GNI in 1955 was about $\$ 710$ billion. $\$ 3.5$ billion/ $\$ 710$ billion is roughly $0.5 \%$.

${ }^{5}$ World Council of Churches (1958), Minutes and Reports of the Eleventh Meeting of the Central Committee of the World Council of Churches: Nyborg Strand, Denmark, August 21-29, 1958 (Geneva: World Council of Churches), Appendix XIV, pp. 124-125.

${ }^{6}$ Proceedings of the United Nations Conference on Trade and Development, Second Session, New Delhi, 1 February-29 March 1968, Volume IV, Problems and policies of financing, Table 8, p. 26.

${ }^{7}$ UN General Assembly resolution 1522, December 15, 1960. This was reaffirmed in identical language in GA resolution 1711, December 19, 1961.
} 
production. This seemed satisfactory to Mr. [Secretary of State Dean] Rusk”, and that the State Department told all its European missions that "we can perhaps set as a collective target a sum of one per cent of our aggregate income". 8

\section{Academic sanction}

It so happened that concurrent research by a group of very influential economists confirmed 1\% of rich-country GNI as roughly the correct number. They included Paul Rosenstein-Rodan and Hollis Chenery, two of the first to hold the position now known as Chief Economist of the World Bank. Both carried out separate, sophisticated back-of-theenvelope calculations of how much foreign capital would be needed by low-income countries in the early 1960s. ${ }^{9}$ They based their estimates on theoretical work in the 1940s and 50s by Oxford's Sir Roy Harrod and MIT's Evsey Domar, drawing inspiration also from the work of W. W. Rostow, an MIT professor who became a top advisor to the Kennedy and Johnson administrations.

The work of Harrod and Domar ${ }^{10}$ provided the first modern growth model and explored the consequences for employment and other economic variables of changes in the capital stock, assuming a simple and mechanistic link between capital and growth that was appropriate for their purposes. Rostow's surveys of developed countries' historical experience $^{11}$ concluded that a necessary (though not sufficient) condition of the "take-off into self-sustained growth" was "a rise in the rate of productive investment from (say) 5\% or less to over $10 \%$ of national income.” Rosenstein-Rodan and Chenery separately took a mechanistic relationship between capital and growth in developing countries related to Harrod and Domar's, and asked how much additional capital would be necessary to bring them to something like Rostow's take-off point.

Though their work was certainly more nuanced, at its core it estimated the capital requirement as the difference between domestic savings in poor countries and the amount of investment needed to achieve a certain amount of growth in Harrod and Domar's

\footnotetext{
${ }^{8}$ Undersecretary of State for Economic and Agricultural Affairs George Ball and Secretary of State Dean Rusk discussed a target of 1\% of GDP. A White House memo from March 17, 1961 states that "Mr. Ball reviewed the problem of burden sharing and indicated that he thought the Germans might agree to one per cent of gross national production. This seemed satisfactory to Mr. Rusk.” Source: U.S. Department of State, FRUS, 1961-63, Vol. IX: Foreign Economic Policy, Office of the Historian, Document No. 97, http://dosfan.lib.uic.edu/ERC/frus/frus61-63ix/06_Section_6.html, accessed June 30, 2005. Later in the day on March 17, 1961, James C. Lobenstine of the US Dept. of State drafted a circular telegram that was transmitted to the US diplomatic missions in Bonn, Brussels, The Hague, Lisbon, London, Ottawa, Paris, Rome, Bern, Dublin, Madrid, Stockholm, Tokyo, and Vienna. It was approved by George Ball. It discusses preparations for the March 27-29 meeting of the OECD's Development Assistance Group (DAG), the first such meeting since the US joined the OECD. Section (c)(2) of the telegram says, "What is required is an increased, long-term, joint effort to help meet the needs of the developing countries. For this purpose, we can perhaps set as a collective target a sum of one per cent of our aggregate income.” Source: U.S. Department of State, FRUS, 1961-63, Vol. IX: Foreign Economic Policy, Office of the Historian, Document No. 98. http://dosfan.lib.uic.edu/ERC/frus/frus61-63ix/06_Section_6.html, accessed June 30, 2005.

${ }^{9}$ P. N. Rosenstein-Rodan (1961), "International aid for undeveloped countries" Review of Economics and Statistics 43 (2): 107-138. Hollis B. Chenery and Alan M. Strout (1966), "Foreign assistance and economic development”, American Economic Review 56 (4): 679-733.

${ }^{10}$ Inter alia Evsey D. Domar (1946), “Capital expansion, rate of growth, and employment”, Econometrica 14 (2): 137-147.

${ }^{11}$ W. W. Rostow (1956), “The take-off into self-sustained growth”, Economic Journal 66 (261): 25-48. W. W. Rostow (1959), “The stages of economic growth” Economic History Review 12 (1): 1-16.
} 
model. To take a simplified example: If $\$ 4$ of capital produce $\$ 1$ of output per year, and $5 \%$ annual growth in output is required, then $5 \%$ growth in capital is required as well. If output is $\$ 100$ million, then investment that year must be $5 \% \times \$ 400$ million $=\$ 20$ million. If national savings is only $\$ 15$ million, then about $\$ 5$ million in external capital is required.

Using more sophisticated but essentially similar techniques, Rosenstein-Rodan arrived at an estimate of developing-country capital needs of \$5.7 billion per year for the early 1960s and rising over that decade. Chenery, using a model augmented to account not only for the gap between savings and investment but also the gap between exports and a postulated "minimum import level", estimated a foreign capital requirement of \$7.4 billion in 1962 and $\$ 10-17$ billion by $1970 .^{12}$ This was taken as necessary for a GNI growth rate of about 5\% in the developing countries, precisely the growth goal set in the declaration of the first United Nations Development Decade in $1960 .{ }^{13} \mathrm{UN}$ documents of the time specifically cite these academic estimates of capital requirements. ${ }^{14}$

The national incomes of the high-income OECD countries in 1961 totaled $\$ 1.03$ trillion. ${ }^{15}$ In other words, the academic estimates of capital requirements in the developing world, on the order of $\$ 10$ billion, happened to equal 1\% of rich-country income. This number thus had both the endorsement of the General Assembly and the imprimatur of some of the top economists of the day, a combined political and academic pedigree that seems a mix of coincidence and coevolution.

\section{From $1 \%$ capital goal to $0.7 \%$ aid goal}

A final step remained for this " $1 \%$ " goal for aggregate capital flows to become the modern " $0.7 \%$ " goal for aid. The first meeting of the United Nations Conference on Trade and Development (UNCTAD) in 1964 noted that capital flows to developing countries had reached $0.8 \%$ of rich-country income in 1961, approximately three quarters of which were official bilateral aid. ${ }^{16}$ The meeting thus hinted at, but did not adopt, an aid goal. The Conference's final act stated that it "recommends" that "[e]ach economically advanced country should endeavor to supply ... financial resources to the developing countries of a minimum net amount approaching as nearly as possible to 1 per cent of its national income ..."17 An aid goal was not only absent but notably and explicitly ruled out: "This is not intended to represent either a ceiling or a suitable method for comparing the appropriate quantitative or qualitative development assistance efforts between economically advanced countries."18

The second meeting of UNCTAD, in New Delhi in 1968, went one step further but stopped just short of a formal aid target. Background studies by the UNCTAD secretariat

\footnotetext{
${ }^{12}$ Chenery and Strout op. cit. p. 722.

${ }^{13}$ UN General Assembly resolution 1710 (XVI), December 19, 1961.

${ }^{14}$ E.g. Rosenstein-Rodan's estimate is cited on p. 15, footnote 10, in the UNCTAD proceedings at Geneva 1964, Vol. V, op. cit.

${ }^{15}$ GNI, current US dollars. World Bank (2005), World Development Indicators 2005, CD-ROM (Washington, DC: World Bank).

${ }^{16}$ UNCTAD proceedings at Geneva 1964, Vol. V, op. cit., p. 15.

${ }^{17}$ Proceedings of the United Nations Conference on Trade and Development, Geneva, 23 March-16 June 1964, Volume I, Final Act and Report, Annex A.IV.2, Section III.4, p. 44

${ }^{18}$ Ibid., Annex A.IV.2, Section III.5, p. 44.
} 
noted that combined public and private capital flows had slipped from $0.87 \%$ of richcountry GNI to $0.62 \%$ over $1961-1966 .{ }^{19}$ These background studies-which were not endorsed by the delegates_-suggested that to meet the General Assembly's one percent goal for total capital flows, "it would be desirable to have a target for official development assistance as a measure of the commitment of governments to international development" and "consistent with the 1 per cent target, ... [c] ]ountries whose net official assistance is currently below 0.75 per cent of their GNP might undertake to raise it to this level by, say, 1971."20 To arrive at this number, the study explicitly assumes that official flows would continue to represent roughly two thirds to three quarters of total capital flows through the mid 1970s. ${ }^{21}$

Though the Conference reiterated support for the $1 \%$ goal of total capital flows, it did not adopt the secretariat's suggestion of an aid goal. The Conference's "decision" on an "aid volume target” reads: "A number of developed countries stated that within the 1 per cent target defined above, they were prepared to attempt to provide a minimum of 0.75 per cent of their GNP by way of net official financial resource transfers. One developed country expressed the view that this proportion should be at least half of the 1 per cent target. The other developed countries, even though they are not prepared to accept any precise ratio, believe that endeavors should be made to ensure that official bilateral and multilateral flows represent a substantial part of the totality of financial resources provided."22 The anonymity of these references suggests deep and sensitive divisions at the meeting.

The aid community wanted more. World Bank President Robert McNamara together with British Minister of Overseas Development Lord Reginald Prentice conceived the Commission on International Development-more commonly known as the "Pearson Commission" after its chair, former Canadian prime minister and Nobel laureate Lester Pearson. The main purpose of the group was to use the commissioners' political clout to draw attention to the UNCTAD target in legislatures, especially the United States. ${ }^{23}$ From its inception, the Pearson Commission was conceived in order to "rejuvenate the commitment to the UNCTAD target... The Commissioners were largely 'political influentials' and well-known economists to help persuade legislatures, with the US as a prime target," explains Ernest Stern, who was Deputy Staff Director for the Commission. $^{24}$

Arrival at the $0.7 \%$ figure was also the result of an arbitrary compromise based on what was thought politically feasible at the time. Former Pearson Commission staffer Sartaj Aziz recalls:

\footnotetext{
${ }^{19}$ UNCTAD proceedings at New Delhi 1968, Vol. IV, op. cit., "Growth and external development finance: study by the secretariat of UNCTAD”, TD/7/Supp.1, p. 13.

${ }^{20}$ Ibid., "Growth, development financing, and aid: issues and proposals. Study by the UNCTAD secretariat”, TD/7, pp. 3, 4.

${ }^{21}$ Ibid., paragraph 9, p. 2.

${ }^{22}$ Proceedings of the United Nations Conference on Trade and Development, Second Session, New Delhi, 1 February-29 March 1968, Volume I, Report and Annexes, Agenda item 12, Section 27 (II), paragraph 7, p. 39. Dated March 28, 1968.

${ }^{23}$ The Commission members, in addition to Pearson, were Sir Edward Boyle (UK), Roberto de Oliviera Campos (Brazil), C. Douglas Dillon (US), Wilfried Guth (Germany), W. Arthur Lewis (Jamaica), Robert Marjolin (France), and Saburo Okita (Japan).

${ }^{24}$ Personal communication with the authors, July 2005. Stern later became Managing Director of the World Bank.
} 
By the time the Pearson Commission met, there was a virtual consensus on the $1 \%$ target. From there, the rationale for reaching the $0.70 \%$ target for ODA was straightforward. ODA had already reached $0.54 \%$ in 1961 . An increase to $0.6 \%$ would have been considered too modest since countries like France had reached $0.72 \%$ by 1968 . I remember one staff discussion in which we debated whether the ODA target should be $0.70 \%$ or $0.75 \%$. Consensus reached was in favor of $0.70 \%$, as a 'simple, attainable and adequate' target. ${ }^{25}$

The final report, delivered to McNamara in September 1969, read: "We therefore recommend that each aid-giver increase commitments of official development assistance for net disbursements to reach 0.70 per cent of its gross national product by 1975 or shortly thereafter, but in no case later than 1980."26

The UN took on the $0.7 \%$ figure, but agreed that governments would exert "efforts" to reach it rather than agreeing to actually reach it. On November 19, 1970, the General Assembly adopted without vote the declaration of the Second Development Decade, calling for six percent GNI growth in developing countries and stating, "Each economically advanced country will progressively increase its official development assistance to the developing countries and will exert its best efforts to reach a minimum net amount of 0.7 per cent of its gross national product ... by the middle of the Decade., ${ }^{27}$ What constituted sufficient effort was not defined.

The General Assembly's declaration of the Third Development Decade in 1980, again adopted without vote, called for yet higher average GNI growth in the developing countries — seven percent-and stated that a "rapid and substantial increase will be made in official development assistance by all developed countries, and where possible surpassing the agreed international target of 0.7 per cent of the gross national product of developed countries."28 The declaration of the Fourth Development Decade in 1990 retained the seven percent growth goal and stated that "[d]onor countries should, in the 1990s, implement such undertakings as they have made to reach or surpass" the $0.7 \%$ aid target. $^{29}$ The $0.7 \%$ figure was mentioned in UN declarations at the 1992 Conference on Environment and Development or "Earth Summit" in Rio de Janeiro, the 1995 World Summit for Social Development in Copenhagen, and the 2002 World Summit on Sustainable Development in Johannesburg, ${ }^{30}$ among other meetings.

The most recent and high profile statement on the aid goal occurred at the UN's 2002 International Conference on Financing for Development in Monterrey, Mexico. Its consensus declaration stated that "we urge developed countries that have not done so to make concrete efforts toward the target of 0.7 per cent of gross national product (GNP) as

\footnotetext{
${ }^{25}$ Personal communication with the authors, July 2005. Aziz later became Finance Minister and then Foreign Minister for Pakistan. See also “Minutes of the Meeting of the Peterson Task Force,” October 16, 1969 for confirmation of this view by Pearson Commission member Douglas Dillon.

${ }^{26}$ Lester B. Pearson and others (1969), Partners in Development: Report of the Commission on International Development (New York: Praeger Publishers), pp. 148-149.

${ }^{27}$ UN General Assembly resolution 2626 (XXV), paragraph 43, November 19, 1970.

${ }^{28}$ UN General Assembly resolution A/RES/35/56, paragraphs 20 and 24, December 5, 1980.

${ }^{29}$ UN General Assembly resolution A/RES/45/199, paragraphs 17 and 40, December 21, 1990.

${ }^{30}$ UN documents A/CONF.151/26/REV.1; A/CONF.166/9; and A/CONF.199/20.
} 
ODA [Official Development Assistance] to developing countries ...”31 This statement was seen to bear greater weight than other endorsements of the goal. Unlike previous meetings at which UN representatives had supported the goal, the Monterrey conference was personally attended by 50 heads of state or government, including those of Belgium, Canada, Finland, France, Norway, Spain, and the United States.

\section{Rich country commitments}

It is notable that none of the above international statements on the $0.7 \%$ goal amount to a promise attain it. In 1960 the General Assembly expressed the "hope" that capital flows would reach $1 \%$ of rich-country income. In 1964, UNCTAD I explicitly stated that this expression of hope was "not intended to represent ... a suitable method for comparing ... development assistance efforts between economically advanced countries.” In 1968, UNCTAD II stated that several developed countries were "not prepared to accept any precise ratio". In 1970, the General Assembly pledged to "progressively increase” aid, and "exert its best efforts" to reach the goal-not to reach it per se. In 1980 the General Assembly promised a "rapid and substantial" increase in aid, but that would only exceed $0.7 \%$ of donor GNI "where possible". Most recently, the heads of state at Monterrey in 2002 promised to "make concrete efforts toward" the goal, not to reach it.

\section{US “aversion to targetry”}

It is also clear that, while the Pearson Commission recommendation of $0.7 \%$ gained traction within the UN system and over time among some European governments, it never was able to convince the United States. President Richard Nixon initiated his own Task Force on International Development in 1969, chaired by Bank of America CEO Rudolph Peterson, to order to re-examine US foreign aid. One of the task force's main questions to consider was "Should the U.S. support the official target of one percent of GNP devoted to foreign assistance?"32 In the end, the task force recommended that aid be increased and a range of qualitative enhancements (such as greater use of multilateral channels), but took no position on the aid target.

The administration followed Peterson's lead and explicitly did not commit to the Pearson target for both substantive and political reasons. ${ }^{33}$ C. Fred Bergsten, Special Assistant for International Economic Affairs at the National Security Council (in practice the lead advisor to Nixon on aid issues during the time of the Pearson Commission) claims:

I was never convinced of the intellectual case for the $0.7 \%$ goal, plus we were quite confident that it would not be helpful to go to Congress and urge them to reach a $0.7 \%$ target....In fact I was careful to avoid committing to it because I thought it would be counterproductive in the Congress....We studiously avoided it. ${ }^{34}$

\footnotetext{
${ }^{31}$ UN document A/CONF.198/11.

${ }^{32}$ Minutes of First Meeting of the Peterson Task Force, September 24, 1969, p. 3.

33 The administration prepared new foreign aid legislation based on the Peterson Task Force recommendations, but it was never voted on as Congressional attention moved to Southeast Asia following the US invasion of Cambodia.

${ }^{34}$ Personal communication with the authors, July 2005. Bergsten was at the NSC 1969-71 and at the US Treasury 1977-81.
} 
Documents from that period suggest that the aid target was seriously debated inside the White House, but ultimately rejected. One National Security Council memorandum to Nixon summarizes the internal discussions:

The [Peterson Task Force] Report does not endorse any aid targets. We believe that the Peterson approach, with its emphasis on need and LDC performance, is the only feasible one with the Congress. Nonetheless, our failure to endorse a target would raise serious political problems in the U.N. and may be used as a justification for less support by other donors. We should accordingly consider whether it is feasible for us to support the principle of a global aid target while at the same time indicating that we could not subscribe to any specific date for attaining it. Alternatively, we may wish to accept the implicit Peterson approach and emphasize our intent to seek higher levels but not subscribe to unattainable targets. This would be pleasing domestically to some in Congress and demonstrate a realistic policy to other countries that we are moving away from promises we cannot fill. ${ }^{35}$

Secretary of State William Rogers and US Ambassador to the UN Charles Yost appear to be the main proponents, with both arguing in the months before the October $1970 \mathrm{UN}$ Summit for the President to agree to the $1 \%$ target for total public and private flows. But National Security Advisor Henry Kissinger took the view that "[t]he U.S. will avoid any pledges to meet the international targets relating foreign assistance to GNP, but will seek to minimize damaging their usefulness to other donor countries." 36 He sought to "balance our aversion to targetry with the foreign policy importance of avoiding a negative stance toward the Second UN Development Decade, and on aid levels in general." ${ }^{\text {37 }}$ Most importantly, in the end President Nixon "rejected committing to setting unattainable targets." 38 Thus the Nixon administration did not formally commit itself to the $0.7 \%$ goal or any timetable - and no US administration since has changed this official position, either directly or through the UN.

\section{Continuing influence}

No rich country, in any of these international fora prior to 2005, promised to actually give $0.7 \%$ of its income in development aid. In these documents, they promised to walk uphill, but not to attain the summit. In 2005, for the first time ever, individual donors have unilaterally pledged to actually reach $0.7 \%$ of GDP by $2015 .^{39}$ At the time of this writing, Britain, France, Finland, Ireland, Belgium and Spain have made such a promise. Germany, Italy, and Portugal have made qualified commitments to the goal, conditional

\footnotetext{
${ }^{35}$ Memorandum From the Chairman of the National Security Council Under Secretaries Committee to President Nixon, Washington, March 25, 1970.

${ }^{36}$ National Security Decision Memorandum 76, Washington, August 10, 1970 (signed by Henry Kissinger).

${ }^{37}$ Action Memorandum From the President's Assistant for National Security Affairs to President Nixon, Washington, undated (attached to October 5, 1970 memo)

${ }^{38}$ May 28 memorandum from Bergsten to Kissinger, cited in editorial note in Foreign Relations, 19691976, Volume IV, Foreign Assistance, International Development, Trade Policies, 1969-1972. US State Department, Office of the Historian (2002).

${ }^{39}$ Council of the European Union (2005), Press Release 8817/05 (Presse 112), 2660 ${ }^{\text {th }}$ Council meeting, Brussels, 23 and 24 May 2005, p. 22. http://ue.eu.int/ueDocs/cms_Data/docs/pressData/en/gena/85008.pdf, accessed July 1, 2005.
} 
on domestic budget processes and without a firm timetable. ${ }^{40}$ Five countries—praised by the Dutch Development Cooperation Minister as the "G 0.7" Norway, Sweden, Denmark, Luxembourg, and the Netherlands.

The Europeans may have settled on this 'accepted' number largely because the press and nongovernmental actors have focused intensively on the $0.7 \%$ figure. In just the 12 months leading up to June 2005, the $0.7 \%$ aid goal was mentioned 407 times in the world's top 50 English-language newspapers. ${ }^{42}$ The number of these mentions has grown over time: just 45 during 1980-1984, but 381 during 1990-1994, and 584 during 20002004. Oxfam currently calls the $0.7 \%$ goal "the long-promised UN aid target", ${ }^{43}$ while InterAction exasperatedly refers to the goal as "a commitment made by the international community in 1969!"44 The target has also inspired a number of specific " 0.7 campaigns," for example, by ActionAid or the British Overseas NGOs for Development (BOND) network. ${ }^{45}$ International organizations have joined in: James Wolfensohn, president of the World Bank from 1995 through early 2005, repeatedly called on rich country governments to honor their "commitment" to the $0.7 \%$ goal. ${ }^{46} \mathrm{UN}$ Secretary General Kofi Annan has also called on developed countries to "commit themselves to reach, by 2015, the target of spending 0.7 per cent of their gross domestic product on official development assistance.",47

\section{Does the 0.7\% goal make sense? Did it ever?}

Despite its durability and seeming simplicity, the $0.7 \%$ aid target no longer makes sense as a benchmark for the level of resources rich countries should devote to helping poor ones. This is the case for three basic reasons: the world has changed radically since the target was initially set; the method for arriving at the target is no longer considered credible; and the seemingly backward premise of determining the correct size of aid flows to poor countries based on the size of rich economies.

\section{Plugging today's numbers into the model used to calculate the original goal}

The academic growth models of the 1950s used global conditions at the time-income levels, savings rates, and global capital flows - to make estimates of the total 'financing gap' which could be filled by aid to allow poor countries to reach a desirable rate of economic growth. Setting aside for a moment whether such an approach is grounded in

\footnotetext{
${ }^{40}$ Inter-Press Service (2005), “Development: EU to Increase Aid”, May 24. http://ipsnews.net/new_nota.asp?idnews=28801, accessed July 1, 2005.

${ }^{41}$ Eveline Herfkens (2002), "Speaking points", United Nations Financing for Development Conference, Monterrey, Mexico, March 22, 2002. http://www.un.org/ffd/statements/netherlandsE.htm, accessed July 1, 2005.

42 Search in Lexis-Nexis Academic Universe database, search terms " 0.7 percent” and "development” and "aid” in full text, category "General News”, Source "Major Papers”, Time period "Previous year”, accessed July 1, 2005.

${ }^{43}$ Oxfam (2005), “Global Anti-Poverty Coalition challenges EU heads of state to do more for the world's poorest”, press release, June 15. http://www.oxfam.org/eng/pr050615_eu_gcap.htm, accessed July 1, 2005.

${ }^{44}$ Emira Woods (2002), "Reflections on Monterrey”, Committee on Development Policy and Practice, InterAction. http://www.interaction.org/development/reflections.html, accessed July 1, 2005.

${ }^{45}$ www.actionaid.org and www.bond.org.uk; see also www.one.org.

${ }^{46}$ Inter alia James Wolfensohn (2004), “Statement at Africa Development Forum”, Addis Ababa, Ethiopia, October 15, 2004, www.worldbank.org/news, accessed July 1, 2005.

${ }^{47}$ Kofi Annan, Statement to the UN General Assembly, New York, 21 March 2005; see also http://www.unmillenniumproject.org/press/0_7.htm for more references to the 0.7 target.
} 
reality (see below), these conditions have certainly changed radically over the past halfcentury.

Figure 1 asks what would happen if we took essentially the same method used to estimate the original capital requirement in the 1960s and applied it to today's numbers. We use a GDP growth target of six percent (the UN target of the Second Development Decade), only consider the 58 poorest countries (those classified as 'low income' by the World Bank), ${ }^{48}$ and assume that each $\$ 3.50$ of capital produces $\$ 1$ of output (the 1960s researchers used either \$3 or \$4). In the early 1960s-here we take 1963 as the reference year - the collective GDP of those countries was $\$ 98.5$ billion in current (1963) dollars. ${ }^{49}$ If each dollar of GDP requires $\$ 3.50$ of capital, then growing at 6\% requires $\$ 98.5$ billion $\times 3.5 \times 0.06=\$ 20.6$ billion in investment. In 1963, gross domestic savings in those countries was $13.1 \%$ of GDP, or $\$ 12.9$ billion. In this simplistic framework, that means the capital requirement from abroad was $\$ 7.8$ billion (or $\$ 20.6$ billion minus $\$ 12.9$ billion). Total GDP of the high-income OECD countries in 1963 was $\$ 1.23$ trillion, so the capital 'need' of the low-income countries in 1960 was $0.64 \%$ of rich-country GDP. Repeating the exercise for all developing countries-including the middle-income countries-gives us a figure of about $1 \%$ for the early 1960s (see Table 1). This is exactly in line with the initial estimates that led to the current target.

But over the next four decades, all of these conditions changed. First, gross domestic savings in the low-income countries rose to $20.3 \%$ by 2003 ; for developing countries as a whole it rose from about $18 \%$ to $28 \%$. Second, the rich countries got much richer-their collective GDP rose by a factor of 3.7 from 1960 to 2003 in real terms. ${ }^{50}$ Today, even the poorest countries have much more domestic capital now than they did in the 1960s and filling any gap between that domestic capital and any given capital 'need' would take a smaller fraction of rich countries' vastly expanded wealth. For these reasons the 'financing gap' for low-income countries declines to $0.03 \%$ of rich-countries' collective income by 2003 - much less than actual net capital flows (both public and private) that reached low-income countries in that year. ${ }^{51}$ The capital 'need' for developing countries as a whole is, by this odd method, negative. This calculation is summarized in Table 1. In other words, if today we were to use the same techniques used to arrive at the $1 \%$ capital goal and consequent $0.7 \%$ aid goal, we would find that the goal was met years ago. We point this out not to claim that current capital flows are sufficient or insufficient, but rather to reveal the hollowness of the method and therefore of the capital target itself. In the appendix we show that this conclusion is not sensitive to a reasonable range of parameter assumptions.

\footnotetext{
${ }^{48} 61$ countries fit the World Bank 'low income' classification but there are insufficient data for the Democratic People’s Republic of Korea, Liberia, and Timor Leste.

${ }^{49}$ Figures are from the World Bank (2005), World Development Indicators 2005 CD-ROM (Washington, DC: World Bank).

${ }^{50}$ Table 1 shows nominal GDP in current dollars, not real GDP, thus high-income OECD GDP increases by a factor of 23.1 from 1963 to 2003.

${ }^{51}$ From World Bank (2005), Global Development Finance 2005 CD-ROM (Washington, DC: World

Bank). See Appendix for results with different parameter assumptions.
} 
Figure 1: Using the same technique used to calculate the original aid target, we arrive at a capital 'need' in low-income countries that is below current flows

\section{Low-income countries only}

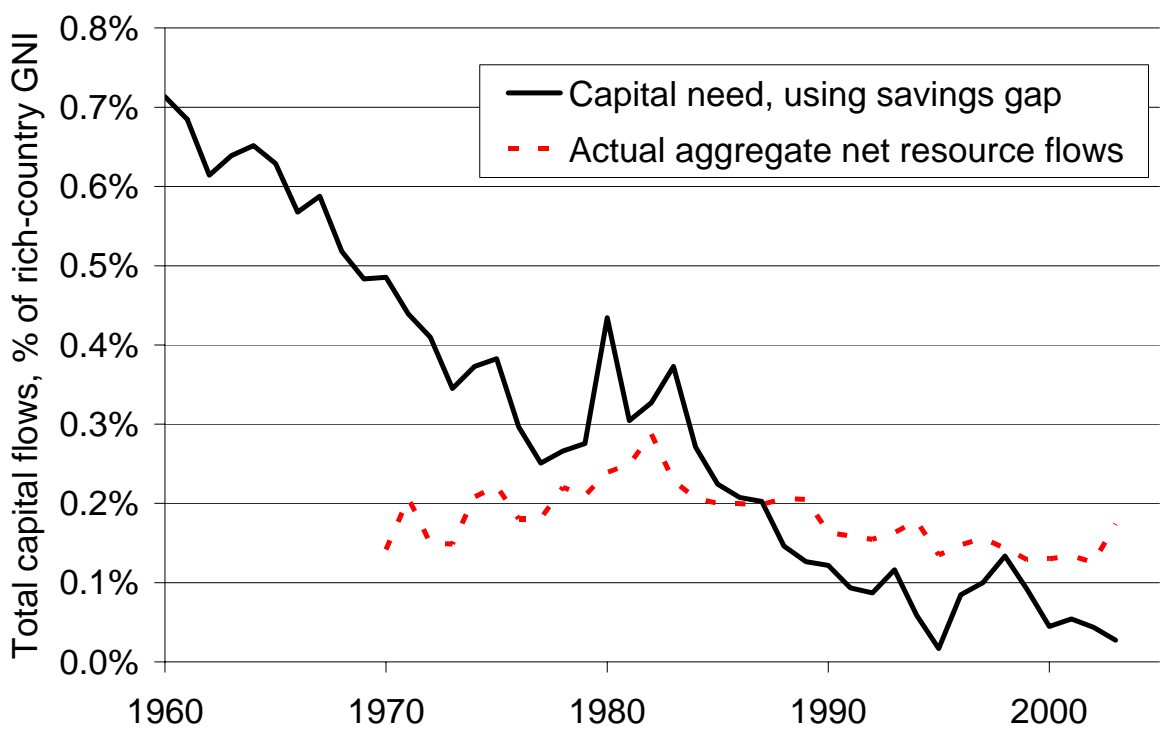

Low- and middle-income countries

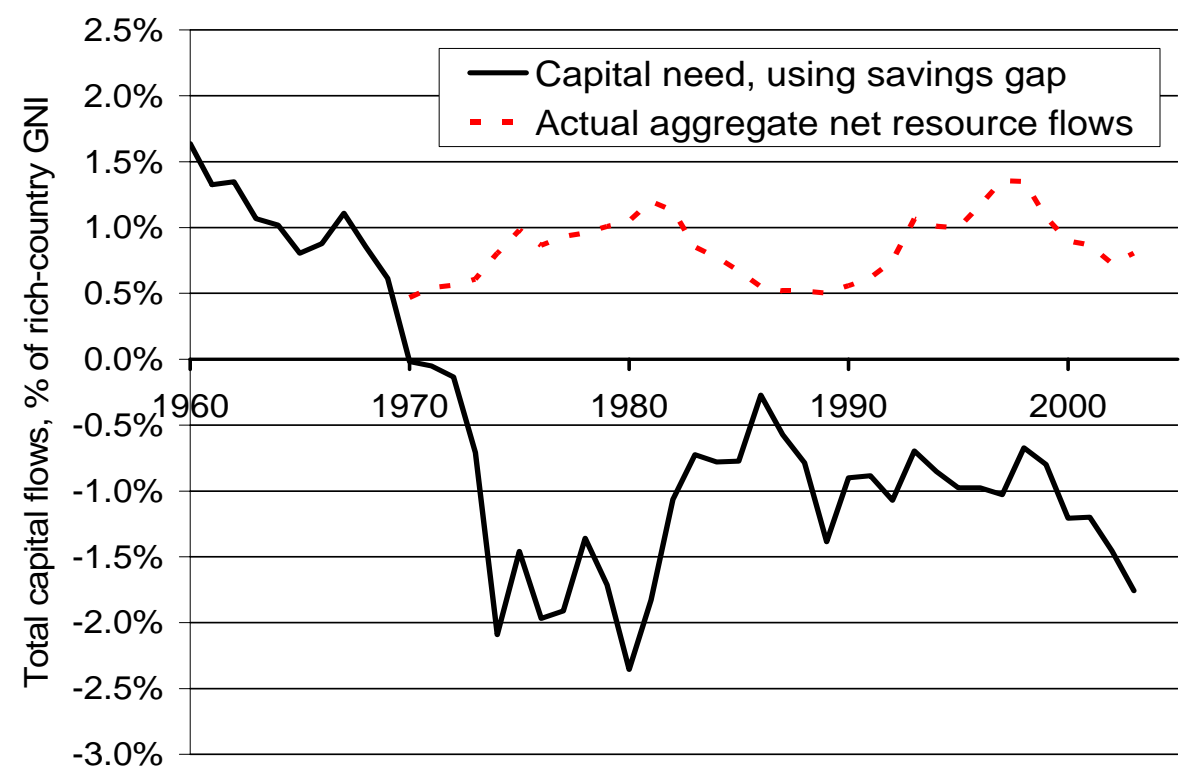

'Low-income' countries are the 61 defined by the World Bank as those with 2003 GNI per capita below US\$765; 'Low- and middleincome' countries comprise the 154 with 2003 GNI per capita below US\$9,385. Data on Gross Domestic Savings and GDP come from the World Bank's World Development Indicators 2005 and Aggregate Net Resource Flows from Global Development Finance 2005. Aggregate net resource flows are the sum of net resource flows on long-term debt (excluding IMF) plus net direct foreign investment, portfolio equity flows and official grants (excluding technical cooperation). Net flows (or net lending or net disbursements) are disbursements minus principal repayments. 
Table 1: Plugging today's numbers into the model used for the original aid goal

\begin{tabular}{cccc}
\multicolumn{2}{c}{ Low-income only } & \multicolumn{2}{c}{ Low- and } \\
middle-income \\
1963 & 2003 & 1963 & 2003
\end{tabular}

Actual data $^{52}$

GDP, trillion current US\$

High-income OECD GDP, trillion curr. US\$

Gross Domestic Savings, \% GDP

Aid as a fraction of capital flows ${ }^{53}$

Total net capital flows, $\%$ rich-country GDP ${ }^{54}$

First approach

Assume capital output ratio

Assume growth

$\rightarrow$ Capital need, \% of rich country GDP ${ }^{55}$

Assume constant fraction of capital is aid

$\rightarrow$ Aid need, $\%$ of rich-country GDP ${ }^{56}$

Second approach

Assume $0.7 \%$ of rich-country GDP in aid

Implied total aid flow, billion current US\$

$\rightarrow$ Implied annual GDP growth ${ }^{57}$

$\begin{array}{rrrr}8.6 & 198.6 & 8.6 & 198.6 \\ 6.2 \% & 10.9 \% & 5.7 \% & 8.8 \%\end{array}$

$5.7 \%$

$8.8 \%$
7.125

$\begin{array}{rr}1.226 & 28.370 \\ 17.8 \% & 28.0 \%\end{array}$

$0.75 \quad 0.08$

$0.83 \% \quad 0.81 \%$

$\begin{array}{rrrr}3.5 & 3.5 & 3.5 & 3.5 \\ 6 \% & 6 \% & 6 \% & 6 \% \\ 0.64 \% & 0.03 \% & 1.07 \% & -1.76 \% \\ & & & \\ 0.48 \% & 0.01 \% & 0.80 \% & -0.14 \%\end{array}$

1.226

0.75

$20.3 \%$

0.36

$0.17 \%$

Table 1 carries this exercise one step further. UNCTAD and the Pearson commission went from the UN's $1 \%$ capital goal to the $0.7 \%$ aid goal by assuming that official aid would continue to represent between two-thirds and three-quarters of all capital flows to developing countries, as it did in the early 1960s. This was not an unreasonable shortterm assumption around 1970. However, recent figures show that the share of private flows has changed substantially. Between 1998 and 2002, gross private capital flows represented an average of $4.8 \%$ of low-income country GDP and aid represented only $2.7 \% .{ }^{58}$ Whereas in the 1960 s only a third of capital flows to the poorest countries was private capital, today only a third is official. Thus, to use the same method of UNCTAD and the Pearson commission to create an aid goal for today, we would take the figure for the total capital requirement of low-income countries from Figure $1-0.03 \%$ of rich-

\footnotetext{
${ }^{52}$ Except where noted, all figures are from the World Bank's World Development Indicators 2005 CDROM and Global Development Finance 2005 CD-ROM.

${ }^{53} 2003$ figures are "Aid (\% of GNI)" divided by the sum of aid and "Gross private capital flows (\% of GDP)", from World Development Indicators 2005 CD-ROM. The 1963 figure is the UNCTAD estimate.

${ }^{54}$ Aggregate net resource flows. 1963 figure for low-income estimated from Figure 1. 1963 figure for lowand middle-income is from Proceedings of the United Nations Conference on Trade and Development, Second Session, New Delhi, 1 February-29 March 1968, Volume IV, Problems and policies of financing, Table 8, p. 26.

${ }^{55}$ Capital 'need' is calculated as $F=Y_{l}(k r-s) / Y_{h}$, where $F$ is capital flow, $Y_{l}$ is aggregate GDP of the World Bank-defined low-income countries in current US\$, $k$ is the capital-output ratio, $r$ is the growth rate expressed as a fraction, $s$ is Gross Domestic Savings as a fraction of GDP, and $Y_{h}$ is aggregate GDP of the high-income OECD countries. See Appendix for results with different parameter assumptions.

${ }^{56}$ Assumes, as in the original UNCTAD analysis, that the fraction of the capital need constituting the aid need equals the fraction of current capital flows to low-income countries that is aid.

${ }^{57}$ Uses the same nomenclature as the above note, $r=\left(\left(F / Y_{l}\right)+\mathrm{s}\right) / k$. Assumes capital-output ratio of 3.5. The qualitative conclusions here are robust to alternative assumptions of 3 or 4 , standard in the 1960s analyses.

${ }^{58}$ World Development Indicators 2005 CD-ROM.
} 
country GDP — and divide it by about three. The resulting 'aid target' is $0.01 \%$ of donor GDP for low-income countries, and negative aid flows to developing countries as a whole. Again, we do not in any way claim that this is the 'right' amount of aid, but only that it lays bare the folly of unreflective commitment to the $0.7 \%$ aid goal, which was calculated in nearly identical fashion four decades ago.

The second approach of Table 1 turns the above calculation on its head. Assuming the model used to calculate the original aid goal was correct-and that poor-country growth depends on the degree to which aid fills the capital gap-how much would poor countries grow if $0.7 \%$ of rich-country GDP flowed as aid? This $0.7 \%$ meant about $\$ 8.6$ billion in 1963 dollars, but by 2003 it meant almost \$200 billion. In 1963, the model suggests that $\$ 8.6$ billion in aid along with then-low domestic savings would promote about 6\% GDP growth in the developing world. This was plausible; over the 1960s, GDP growth was $5.0 \%$ across all developing countries and $4.2 \%$ in low-income countries. ${ }^{59}$

But taking today's higher savings in poor countries, and again assuming that it takes $\$ 3.50$ of capital to raise output by $\$ 1$, the assumptions mean that sending about $\$ 200$ billion per year in aid to low-income countries would cause their aggregate GDP to grow at $11 \%$ per year. To put this in perspective, not one of the 154 low- or middle-income countries in World Bank data had average GDP growth this high between 1980 and 2003. (China was closest at 9.52\%; the next two highest were Botswana at $7.6 \%$ and Bhutan at $6.9 \%$.) The model likewise suggests that sending the same $\$ 200$ billion to all developing countries-including middle-income-would provoke $8.8 \%$ GDP growth. The typical developing country GDP grew at 2.7\% during this period. We stress that we do not suggest this growth would actually occur. We only suggest that there is little modern relevance to a model whose assumptions imply that aid flows alone could spark Chinalike growth rates or better across the entire developing world.

\section{Problems with the Financing Gap Model Itself}

The fundamental problem is that the model assumed above, while suitable to Harrod and Domar's original purposes, is nowhere near to an effective portrait of the process of longterm economic development. The concept of the 'financing gap' is fraught with problems and has not been credible among development economists for decades. Some version of the Harrod-Domar or the associated "two-gap” (savings gap and foreign exchange gap) model is nonetheless still commonly used for estimating how much aid will be needed to reach certain growth targets in aid agencies as a back-of-the-envelope technique. These estimates start from the difference between current growth and the desired rate, suggesting a "growth gap." The approach then uses the incremental capital output ratio (ICOR) to calculate what level of investment is required to reach the growth levels (in our example above we use an ICOR of 3.5), then subtracts domestic savings to get the external financing gap-or the amount of required aid. The problem is that, in practice, the financing gap model does not work. Economist Bill Easterly demonstrates weak relationships in developing countries all along the aid-to-investment-to-growth chain. ${ }^{60}$ Greater aid does not necessarily lead to higher investment (Easterly in fact finds that the relationship may, on average, even be negative). He also shows that the link from

\footnotetext{
59 Ibid.

${ }^{60}$ William Easterly (1999), “The Ghost of Financing Gap: Testing the Growth Model Used in the International Financial Institutions,” Journal of Development Economics, 60 (2): 423-438.
} 
investment to growth is more complicated than the financing gap model assumes. Indeed, if the financing gap approach had worked as expected over the period 1960-1994, Easterly calculates that Zambia's per capita income would have been $\$ 20,000$, or 33 times the actual figure of about $\$ 600 .^{61}$ Despite the fact that the financing gap approach "fails all theoretical checks and empirical tests," 62 it continues to influence aid allocation today and the rationale for aid targets.

\section{Calculating the 'right' level of aid from donor side rather than recipient side}

Lastly, even if the financing gap model is flawed and the assumptions are out of date, at least that approach starts by looking at recipient countries. The $0.7 \%$ target takes as a given that the right barometer is a static portion of rich country economies. It does not make sense to calculate the requirements of one set of countries based on an (almost wholly) unrelated indicator in a different set of countries. More specifically, why set the 'right' level of aid for poor countries based on the size of rich economies? If a particular country is thought deserving of a particular amount of aid-based on need, a financing gap estimate, or whatever measure- that number likely has no relationship to a different economy, which may be on the other side of the globe and have few direct linkages.

If we take a particular country, say Ghana, and try to determine what level of aid might be appropriate and desirable, the starting point would logically be to start asking about conditions in Ghana. Important questions would include: What are Ghana's development needs? Where are there shortages of capital? What interventions might reasonably be externally financed? What would be the effects of those interventions on Ghanaian institutions, policies, and technology? It would not advance the analysis to ask, 'How big is the French economy?' Ability to pay for a certain policy is only a very small part of rich countries' criteria for domestic spending of public funds; the effects of the policy are of paramount importance. This should be equally true in debates on international spending.

More recent attempts to calculate the worldwide aggregate aid 'need' have not advanced much beyond the backward techniques used to calculate the $0.7 \%$ goal in the $1960 \mathrm{~s}$. Widely cited estimates of a $\$ 50$ billion need in additional aid to meet the Millennium Development Goals, for example, are largely based on two studies-one by a group known as the Zedillo Commission and another by Shanta Devarajan and co-authors at the World Bank. ${ }^{63}$ The Zedillo Commission study based its estimate of capital needed to spark sufficient growth to halve poverty over 25 years-the first Millennium Development Goal-primarily on an UNCTAD study using a mechanistic financing gap model. ${ }^{64}$ That UNCTAD study assumes that if capital flows were to somehow be sufficient to raise investment to 22\% of GDP in Sub-Saharan Africa, real GDP growth in

\footnotetext{
${ }^{61}$ William Easterly (2001). The Elusive Quest for Growth, MIT Press, Cambridge, MA, p. 43.

${ }^{62}$ Easterly (1999) op. cit., p. 437.

63 "Report of the High-Level Panel on Financing for Development", commissioned by UN Secretary General Kofi Annan and prepared by a panel of 11 financial experts under the leadership of former Mexican president Ernesto Zedillo, presented to Annan on June 28, 2001. www.un.org/reports/financing, accessed July 7, 2005; Shantayanan Devarajan, Margaret J. Miller, and Eric V. Swanson (2002), ”Goals for Development: History, Prospects, and Costs,” Policy Research Working Paper 2819, World Bank, Washington, DC.

${ }^{64}$ United Nations Conference on Trade and Development (2000), Capital Flows and Growth in Africa (New York: United Nations). The "Report of the High-Level Panel” op. cit. cites this UNCTAD study on p. 30.
} 
that region would necessarily be $6 \%$ per year. Unfortunately for simplistic models of this kind, the assumptions that in Africa (a) all aid becomes investment and (b) all investment becomes growth have no empirical support. The evidence is very strong that Africa's growth performance has been weak not from a lack of capital per se, but from low productivity of that capital. ${ }^{65}$ This model estimates roughly a $\$ 10$ billion capital 'need' for Africa, which the Zedillo report simply doubles to account for other developing regions. For the rest of the development goals the report throws up its hands: "It is clear that our present knowledge does not suffice to put a convincing price tag, even a rough one, on the cost of meeting the human development goals." ${ }^{66}$ It nevertheless settles on $\$ 30$ billion for the rest of the goals, for a total of $\$ 50$ billion, and uses this final figure throughout its text.

The study by Devarajan and others uses two techniques to arrive at its aid target. The first is a very simple "financing gap" model quite similar to that used in the UNCTAD study. The second attempts to calculate the cost of the goals for education and health attainments by assuming that expenditure levels for currently-served populations, if scaled up to the amounts that would be needed if vastly expanded populations were being served, would actually result in those target populations being universally served. The authors note that such an analysis is beset by "weak, and sometimes contradictory evidence on the relationship between public expenditures [and outcomes]; difficulty in disentangling the complementary roles of supply and demand [for services]; and poor data quality." They conclude by emphasizing "that these estimates are extremely crude, and based on a host of heroic assumptions, many of which may not be borne out as history unfolds. ... [W]e cannot stress enough the fact that financial assistance is but one of the factors required to reach these goals." 67 Despite reliance by both the Zedillo estimates and the Devarajan et al. estimates on the flawed financing gap model—and oftforgotten caveats by Devarajan et al. that their complementary estimates are extremely crude, may be way off, and do not suggest that such expenditures per se would actually cause the goals to be met-their independent $\$ 50$ billion estimates have been widely cited as the new aid 'need'. 68

But these contemporary estimates do not serve as anything like modern justifications of the $0.7 \%$ aid goal, for two reasons. First, they are calculated using flawed techniques remarkably similar to those used in the early 1960s. Second, even if they were correct, they would imply a total aid need — an additional $\$ 50$ billion to reach a world total of about $\$ 110$ billion per year-representing just $0.35 \%$ of the GDP of the high-income OECD countries. That is, these new estimates suggest that the $0.7 \%$ goal overestimates aid 'need' by one hundred percent.

\footnotetext{
${ }^{65}$ Shantayanan Devarajan, William R. Easterly, and Howard Pack (2003), "Low investment is not the constraint on African development”, Economic Development and Cultural Change 51 (3): 547-571.

66 "Report of the High-Level Panel" op. cit. p. 31.

${ }^{67}$ Devarajan et al. (2002), pp. 22-23 and 30.

${ }^{68}$ For more analysis of the MDG costing studies and the problems associated with pricetags on development outcomes see Michael Clemens, Charles Kenny, and Todd Moss (2004), “The Trouble with the MDGs: Confronting expectations of aid and development success," Working Paper 40, Center for Global Development, Washington DC, May.
} 
One recent estimate that does try to start from the recipient 'need' and add up the costs is the Millennium Project. ${ }^{69}$ Even if one were to accept their methodology and their long list of recommended interventions (many of which are problematic), they nonetheless only arrive at $0.54 \%$ of rich country GNI as the total aid requirement. That is, even the most ambitious estimates suggest that $0.7 \%$ is vastly overstated.

Skepticism over the $0.7 \%$ aid target is not to say that knowing the aid budget relative to a donor's economy is entirely useless. ODA/GNI is a fair indicator of a country's aid budget relative to other spending priorities and arguably could be considered a relative measure of a country's 'generosity' toward international development. But ODA/GNI does not tell us anything about the 'right' absolute size of flows to a particular set of countries.

\section{There is no 'right' fixed target}

There's the rub. The $0.7 \%$ target was always intended as a tool to lobby rich governments to raise their aid budgets - it was never intended to be an actual target for the appropriate level of ODA. It is an arbitrary figure based on a series of outdated assumptions going into a dubious model and measured against the wrong metric. Our reading of the original texts reveals that in no UN forum did any government ever commit to reach the targetthough many pledged to move toward it. Successive US administrations in fact explicitly avoided any such commitment.

Is there any harm in promoting nonsensical goals? For an international aid goal to be useful as an actual practical target, it must be matched to the needs and conditions of recipients and also to the political process and budget priorities of the donors. Our interpretation is that $0.7 \%$ fails both of these tests. Assessing financing needs on the recipient side is extremely difficult; the Zedillo Commission cautions that even a rough price tag is probably impossible. In fact, $0.7 \%$ simply tells us nothing about the real financial requirements of poor countries. Stretching $0.7 \%$ to become a functional target for aid budgets that applies across all donors-as it appears that the UN, activists, and even some governments have come to believe-is to give the target a life and purpose for which was never intended. That no longer makes any sense, if it ever did.

Perhaps more importantly, a goal divorced from political realities could even be counterproductive as a lobbying tool. Many NGOs and aid proponents clearly find that the $0.7 \%$ target is a useful way to urge their own governments to boost their spending on development assistance. In that political role, the target has probably been a success, especially in Europe. However, the $0.7 \%$ target was, almost from its inception, aimed squarely at the United States. The Nixon administration, even as it considered a major overhaul of its foreign aid program, determined that agreeing to the target would prove poisonous with the real appropriators, the US Congress. This is arguably even truer today than 35 years ago. A static global goal based on rich country income may play well in Europe and provide political motivation to increase their aid budgets, but it has the opposite effect in the US where successive administrations have had, as Kissinger put it, an 'aversion to targetry.' The $0.7 \%$ target is thus not only conceptually wrong and

\footnotetext{
${ }^{69}$ Millennium Project (2005), Investing in Development: A Practical Plan to Achieve the Millennium Development Goals, Report to the UN Secretary General.
} 
impractical, but its continued use to shame the US into more than quintupling its aid budget could wind up undermining its original aim. 


\section{APPENDIX: Consequences of different parameter assumptions}

Here we test the sensitivity of the results in Table 1 to different assumptions of capital output ratio and desired recipient-country growth.

In his work in the 1960s, Chenery found a median capital-output ratio of 3.52 (Hollis B. Chenery and Alan M. Strout [1966], "Foreign Assistance and Economic Development”, American Economic Review 56 [4]: 679-733, p.684), though it varied roughly in the range of 3 to 4 across countries in his sample. Other studies of the period (e.g. P. N. Rosenstein-Rodan [1961], "International aid for undeveloped countries" Review of Economics and Statistics 43 [2]: 107-138) used a capital-output ratio of 3. Some modern research estimates a capital-output ratio in the 1990s in many developing countries of closer to 2; we include this assumption as well.

Below we include targeted GDP growth of 5\%, the explicit target in the UN Declaration of the First Development Decade in 1960 (General Assembly resolution 1710 [XVI], December 19, 1961).

\section{Low-income only}

2003

Assume capital output ratio

Assume growth

$\rightarrow$ Capital need, $\%$ of rich country GDP

$\rightarrow$ Aid need, $\%$ of rich-country GDP

Assume capital output ratio

Assume growth

$\rightarrow$ Capital need, $\%$ of rich country GDP

$\rightarrow$ Aid need, $\%$ of rich-country GDP

Assume capital output ratio

Assume growth

$\rightarrow$ Capital need, $\%$ of rich country GDP

$\rightarrow$ Aid need, $\%$ of rich-country GDP

Assume capital output ratio

Assume growth

$\rightarrow$ Capital need, $\%$ of rich country GDP

$\rightarrow$ Aid need, $\%$ of rich-country GDP

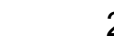

$6 \%$

$-0.08 \%$

$-0.06 \%$

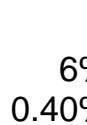

$0.30 \%$

4
$6 \%$
$0.88 \%$

$0.66 \%$

3.5

$0.36 \%$

$0.27 \%$
Low- and middle-income 1963 2003

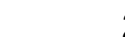

$\begin{array}{rr}2 & 2 \\ 6 \% & 6 \% \\ -1.92 \% & -4.02 \% \\ -1.44 \% & -0.32 \%\end{array}$

$-0.32 \%$

$-0.12 \%$

$-1.44 \%$

$\begin{array}{rr}3 & 3 \\ 6 \% & 6 \% \\ 0.07 \% & -2.51 \% \\ 0.05 \% & -0.20 \%\end{array}$

$-0.03 \%$

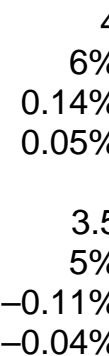

$\begin{array}{rr}4 & 4 \\ 6 \% & 6 \% \\ 2.06 \% & -1.00 \% \\ 1.55 \% & -0.08 \% \\ & \\ 3.5 & 3.5 \\ 5 \% & 5 \% \\ -0.10 \% & -2.64 \% \\ -0.07 \% & -0.21 \%\end{array}$

